Postdoc (mag.art. - Ph.d.), Danmarks Institut for

Pædagogik og Uddannelse, Aarhus Universitet

\title{
TV-KOKKEN SOM KØNSOPDRAGER
}

\section{Styring af køn gennem maddannelse i Jamie's Ministry of Food, The F-word og Le Chef Contre-attaque}

I madprogrammet Jamie's Ministry of Food fra 2008 tager den britiske TVkok Jamie Oliver skridtet fra at være livsstilsekspert til at blive social/moralsk entreprenør, der vil bekæmpe den tiltagende fedmeepedemi i Storbritannien. ITV-serien konstrueres et voyeuristisk middelklasseperspektiv på underklassen; et blik, der patologiserer denne arme klasse gennem et hårdtslående portræt af klassemedlemmernes ulækre og usunde omgang med mad. Børnene er ikke i stand til at spise med kniv og gaffel, og de aner ikke, hvad en frisk tomat er. Ansvaret for dette forfald placeres hos arbejderklassemødrene, da børnenes spisevaner iscenesættes som deres ansvarsområde. Igennem madkurser tilbyder Jamie Oliver i programmet disse kvinder en vej tilbage til et 'sundt' moderskab.

I denne artikel vil jeg argumentere for, at dette program er udtryk for en tendens i moderne britiske og franske madprogrammer, hvor mandlige TV-kokke bruger maddannelse til at disciplinere og 'korrigere' bestemte måder at gøre køn på. Jeg vil fremlægge denne tese gennem analyser af dette program og af to andre eksempler, hvor maddannelse kobles til styring af køn og bestemte kroppe, nemlig 1) The F-word (2005-2010), hvor den hypermaskuline Gordon Ramsay forsøger at disciplinere to postfeministiske kvinder og gennem et kulinarisk make-over leder dem imod deres 
'naturlige' plads i den heteroseksuelle matrice ${ }^{1}$; 2) Le Chef Contre-attaque (2009), hvor den metroseksuelle franske TV-kok Cyril Lignac forsøger at gøre traditionelle franske udkantsmænd til moderne mænd med urbane middelsklasseværdier ved at få dem til at deltage i madlavning i hjemmet.

Fælles for disse eksempler er, at TV-kokken indtager rollen som kønsopdrager, og maddannelse kobles til styringen af 'usunde' måder at gøre køn på. Artiklen påpeger også - modsat anden forskning inden for feltet (Hollows \& Jones; Hollows 2015, Leer 2014b) - at det er forskellige kønsog klassediskurser, der bruges til at illegitimere og korrigere forskellige 'fejlkønnede' kroppe i disse programmer. En central pointe, der er ny i forhold til den eksisterende forskning, er, at TV-kokkenes madaktivisme ikke bare skaber hierarkier mellem mænd og kvinder, men ligeledes også mellem forskellige typer af mænd.

Artiklen anlægger et poststrukturalistisk, performativt blik på mad og køn og anskuer begge dele som "gørelse" og som gensidigt konstituerende praksisser (jf. Leer 20014a, 11). Der trækkes særligt på den amerikanske sociolog Majorie Devaults vigtige analyse af madlavningens kønning (Devault). Heri argumenteres på baggrund af omfattende etnografisk feltarbejde for, at madlavning - særligt den, der foregår i hjemmet - og alle praksisser omkring det at brødføde en familie er med til opretholde en social orden, der privilegerer mænd og fastholder kvinder i en defavoriseret position, da deres arbejdstunge anstrengelser i køkkenet tages for givet. Så snart mænd derimod bevæger sig ud i køkkenet, hyldes de, og for dem er madlavning $\mathrm{i}$ hjemmet et lystbetonet tilvalg og ikke en påtvungen, daglig pligt. DeVaults undersøgelser er fra Amerika i starten af 1990'erne og flere studier tegner et billeder af, at dette billede ikke længere er helt fyldestgørende, da der er opbrud i denne kønning og tegn på at madkulturen kan medføre øget ligestilling i privatsfæren (Arseth og Olsen; Neuman, Gottzén og Fjellström). Jeg vælger alligevel at bruge Devaults

1 "That grid of cultural intelligibility through which bodies, genders and desires are naturalized ... a hegemonic discursive/epistemic model of gender intelligibility that assumes that for bodies to cohere and make sense there must be a stable sex expressed through a stable gender (masculine expresses male, feminine expresses female) that is oppositionally and hierarchically defined through the compulsory practice of heterosexuality" (Butler, 208) 
analyse af madlavningens kønning som et baggrundstæppe for min analyse, da denne kønning stadigvæk vækker genklang, og fordi DeVault har et skarpt blik for intersektionen mellem køn og klasse i madkulturen. Klasseperspektivet synes nemlig også at være tæt forbundet med køn i mine analyseeksempler.

Artiklens teoretiske perspektiv er endvidere inspireret af den anglofone food studies ${ }^{2}$ traditions nyfortolkning af Foucaults gouvernementalitetsbegreb - det man kunne kalde gastrogouvernementalietet - hvor madundervisning og styring kobles til legitimering og illegitimering af bestemte subjektspositioner og moralske regimer. Dette begreb udvikles i næste afsnit, hvor maddannelse konceptualiceres via Foucaults gouvernementalitetetsbegreb. Herefter sættes denne teori i spil gennem analyser af Jamie's Ministry of Food, der læner sig op af tidlige læsninger (Hollows \& Jones, Hollows 2016). Herpå følger to nye analyser af The F-word og Le Chef Contre-attaque, som er udvalgte, da gouvernementaliteten her er bundet op på nogle distinkte køns- og klassediskurser. Analyserne diskuteres afsluttende med henblik på at vise ligheder og forskelle i teksterne. Denne diskussion munder ud i nogle kritiske refleksioner af TV-kokkenes entreprise.

\section{MADDANNELSE OG GASTROGOUVERNEMENTALITET}

Maddannelse har været et centralt begreb i nyere kampagner i forhold til madrelaterede samfundsproblemer (Fuglsang). Ikke desto mindre er der langtfra konsensus om, hvad begrebet dækker over (Benn, 2014). Det gælder også den engelske pendant, food literacy. Det kan i sine enkleste former bare være evnen til at læse og forstå en varedeklaration, men dækker typisk over

2 Food studies dækker over sociologiske og kulturelle studier af mad og adskiller sig herved fra de naturvidenskabelige, teknologiske og ernæringsvidenskabelige studier af mad. Traditionen har været særlig stærk i USA siden 1980'erne med fx grundlæggelsen af tidsskriftet Food and Foodways i 1985, men food studies har bredt sig voldsomt over de sidste år - også i Europa - og opererer ofte med nye tværvidenskabelige tilgange og faglige konstellationer (Belasco, Counihan og Van Esterik). Angående feltets udvikling henvises til (Counihan, Kjær og Leer) og (Povlsen, Kjær og Leer). 
både viden og kompetencer i forhold til mad. Tankegangen i maddannelsesprojekter er ofte, at man ved at højne borgeres maddannelse vil kunne give dem værktøjer til at få større madglæde og bedre sundhed, hvilket på længere sigt vil gavne samfundsøkonomien. Som ved mange andre dannelsesprojekter forstår maddannelsesprojekter sig selv som demokratiske og demokratiserende projekter, der giver det enkelte individ kompetencer til at deltage aktivt og produktivt i samfundslivet og i udformningen af sit eget liv (Benn).

Der har dog i de senere år inden for food studies været et stigende fokus på, hvordan forskellige former for tilbud om maddannelse promoverer og favoriserer bestemte moralske diskurser og identitetsidealer, mens andre ekskluderes. Her har mange hevet fat i Foucaults teorier om styring, viden og magt og ikke mindst hans gourvernementalitetsbegreb.

Gouvernementalitet dækker over de kristne post-machiavelliske samfunds ledelsesstrategier og styringsteknologier, der modsat ældre samfund i mindre grad fokuserer på territoriet og mere direkte på befolkningen (Foucault 2008, 116-118). Gouvernementalitet har undergået forskellige udviklingsstadier, som filosoffen Anders Fogh Jensen påpeger:

Magten har transformeret sig fra en magt til at få til at dø (laisser mourir) til en magt til at få til at overleve (faire vivre). Han [Foucault] bevæger sig samtidigt væk fra en interesse for den disciplinerende magt, idet han begynder at interessere sig for en magt, der snarere gør det gode. Spørgsmålet bliver: hvorledes magtes vi gennem de tilbud om det gode, som vi ikke kan sige nej til? (Fogh Jensen).

En central pointe i Foucaults teori er, at de moderne styringsteknologier er gået fra befaling til anbefaling, men det betyder ikke, at de er mindre styrende. Styringen sker blot mere indirekte og ofte gennem konstruktionen af legitime og illegitime subjektspositioner.

Artiklen Savoir Fare: Are Cooking Skills a New Morality? (Coveney, et al.) bruger gourvernementalitetsbegrebet til at undersøge maddannelsesfeltet. Hvor Foucault fokuserede på et statsligt niveau, så understreger Coveney et al., at gouvernementaliteten - dens logikker og praksisser - også fungerer og findes i mindre sociale enheder, hvilket Foucault ligeledes åbner op for (Foucault 2009, 15). Coveney et al. viser, hvordan forskellige maddannende projekter er bundet op på moralske dagsordener, der kobler 
maddannelse med rigtige og forkerte måder at leve på. 'Maddanneren' er således ikke bare én, der videregiver bestemte færdigheder i køkkenet, men han/hun hjælper også eleven til at vælge én måde at leve på fremfor en anden (Coveney et al, 662). Artiklen demonstrerer endvidere overbevisende, at disse maddannelsesprojekter meget ofte tager udgangspunkt i en form for moralsk panik, som kobles til en fortælling om madkulturens forfald. Denne forfaldsdiagnose legitimerer en disciplinerende intervention i forhold til de uansvarlige borgers mad- og livsvaner. Maddannelsen bliver altså 'et tilbud om det gode, som vi ikke kan sige nej til', men dette tilbud fungerer også som et styringsredskab, der skal få 'eleverne' til at acceptere og underkaste sig de moralske idealer og livsformer, som er koblet til maddannelsen. Med dette gastrogouverrnementalitetsperspektiv fokuserer man altså på, hvordan disse (såkaldte demokratiserende) aktiviteter fungerer styrende i forhold til eleverne, da de i dannelsesforløbet tvinges til at acceptere de prækonstruerede forestillinger om legitime og illegitime livsstile og identiteter.

I denne artikel vil jeg videreføre dette gouvernementalitetsperspektiv, og mine analyser vil fokusere på, hvad det er for nogle legitime/illegitime kønspositioner, der kobles til maddannelsesprojekterne i de tre aktivistiske madprogrammer.

Den aktivistiske madprogramgenre har i de senere år fået en del vind i sejlene i både England og Frankrig med en række forskellige formater, som ofte er styret af mandlige værter (Hollows 2016). Modsat de klassiske 'hyggelige' madprogrammer i TV-køkkenet, hvor kokken demonstrerede tilberedningsformer for seeren, er de aktivistiske formater bundet op på TV-kokkens engagement i et madrelateret problem i det offentlige rum. Her er den narrative kraft ikke så meget madlavningsdemonstrationerne som kendiskokkens kamp for at ændre 'almindelige' menneskers dårlige madvaner. Ved at bruge sin kendisfaktor til at kaste sig over samfundets problemer får TV-kokken således også en mindre overfladisk og mere social engageret profil. Med en vis kynisme kan man argumentere for, at denne celebrity filantropi kan tolkes som en Corporate Social Responsibility-strategi for kokkenes brands (Leer 2014b, 57).

Vi finder også eksempler på genren i en dansk kontekst, hvor det mest prominente eksempel nok er Claus Meyers forsøg på at give fæng- 
selsindsatte en kokkeuddannelse i den kontroversielle serie Restaurant bag tremmer. Her vil jeg dog af pladshensyn kun forholde mig til engelske og franske eksempler. ${ }^{3}$

\section{JAMIE OG DE FORTABTE ARBEJDERKLASSEMØDRE}

Jamie Oliver brød igennem med TV-programmet The Naked Chef (19992001). Dengang var han en ung dynamisk, nyuddannet kok, som lige var flyttet til London. Programmet følger ham, når han lavede mad i sin fritid til forskellige sociale arrangementer. Programmets succes hang ikke mindst sammen med, at han formåede at gøre op med de traditionelle mandlige modeller i TV-køkkenet: den frankofile levemand, som var godt oppe i årene, og den professionelle kok i uniform (Leer 2014a). I The Naked Chef blev madlavning integreret $i$ en ung og hip livsstil, og madlavning blev en måde at forhandle en mobil maskulinitet på, der alternerede mellem nye og gamle maskulinitetsudtryk (Hollows 2003, Moseley 2001).

Med dokumentaren Jamie's Ministry of Food tager Jamie Oliver skridtet fra at være livsstilsekspert, der viser, hvor sjov madlavning kan være, til at være social og moralsk entreprenør, der vil starte en madbevægelse. I dokumentaren følger vi denne kampagne, som udgøres af en række initiativer (madkurser, events) og en kogebog, som akkompagnerer dokumentaren. Målet med denne bevægelse er at bekæmpe den tiltagende fedmeepidemi i Storbritannien ved at få 'folk' til at lave mad fra bunden igen. Igennem skiftet fra livsstilsekspert til moralsk entreprenør ændres hans persona radikalt. Den drengede og flydende maskulinitetsudtryk fra The Naked Chef er erstattet af en indigneret og patriarkalsk maskulinitet.

Dette nye udtryk understøttes af den symbolsk ladede titel: Jamie's Ministry of Food. Storbritannien havde et madministerium under Anden Verdenskrig, hvis formål var at sikre 'hjemmefronten'. Dette blev gjort ved

3 Ang. madprogrammets historie i hhv. Storbritannien og Frankrig henvises til Leer 2014a, særligt kapitel tre om madprogrammets historie og anatomi s. 60-93. Her vil jeg blot påpege, at Frankrig synes med nogle års forsinkelse at have givet madprogrammet en central plads i sendefladen - ikke mindst ved at have overtaget en række formater og tendenser fra den britiske scene. 
at formidle viden til husmødrene om, hvordan man kunne lave god mad $i$ en rationeringstid.

Kogebogen Jamie's Ministry of Food, som er en del af kampagnen, er dedikeret til Marguerite Patten. Hun var en ledende figur i det oprindelige madministerium og blev den første stjerne i britisk mad-tv i efterkrigsårene og frem med programmer som Designed for Women fra 1947. ${ }^{4}$ Hun optræder på et sort/hvidt-foto på en af kogebogens første sider, hvor hun fremstår med et næsten majestætisk udtryk. Denne nostalgiske dyrkelse af Patten og hendes samtid er meget sigende for kampagnens nationalromantiske ånd og dens udtalte ambition om at genrejse nationen (Leer 2014b).

Den aktuelle fedmeepidemi er nemlig ifølge Jamie et resultat af modernismens indtog i Storbritannien. Med denne invasion fulgte nemlig opløsning af traditionelle strukturer og en række livsstilsændringer. Hermed beror Jamie's Ministry of Food på en idyllisering af dengang vi ikke alle gik på arbejde (Oliver, 8). Kvindernes indtog på arbejdsmarkedet markerer herved en skillelinje mellem en god, gammel fortid, hvor sunday roasts samlede familien, og en nutid, hvor både måltidskulturen og familien er i opløsning. Jamie Olivers projekt beror altså på følgende logik: Den dårlige madkultur og fedmeepidemien er udtryk for en større kulturel krise og nedbrydning af traditionelle strukturer og samlingspunkter. Heldigvis tilbyder Jamie en løsning på den kulinariske krise, som også kan afhjælpe den kulturelle krise og genopbygge nationen til fordums storhed. Det er naturligvis ikke tilfældigt, at den periode, som Jamie fremhæver i sin nostalgiske mytologisering, er tiden omkring Anden Verdenskrig. Det var vel sidste gang, Storbritannien for alvor kunne kalde sig et stort rige. Siden dengang er storheden - og den monokulturelle enhed - blevet svækket af afkolonialisering, ungdomsoprør, eksperimenter med velfærdsstaten, kvindefrigørelse ...

4 Marguerite Pattens var adresseret datidens husmødre i en tid, hvor kvinderne gjorde deres indtog på arbejdsmarkedet, og hvor kvinderollen i kølvandet på anden verdenskrig var til debat: 'In these programmes, the postwar British woman, is both producer and produced, her expertice simultaneously acknowledged, valued and publicly corrected and delimited by television" (Moseley, 2009). 
IJamie's Ministry of Food gøres nutidens arbejderklassemødre ansvarlige for nationens kulinariske og kulturelle forfald. Det kommer måske mest eksplicit til udtryk i dokumentaren. Serien demonstrer indledningsvis, hvor slemt det står til i Storbritanniens lavere klasser. Jamie er taget til Rotherham, en arbejderklasseby i Nordengland, der har den stigmatiserende rekord af at være Englands 'fedeste' by. Byens overvægtige borgere modstilles den dynamiske middelklasseurbanitet, som Jamie repræsenterer, og som seeren inviteres til at identificere sig med. I seriens åbning kommer vi hjem til en 'typisk' familie, hvor moderen Natasha er ved at servere endnu en take-away-middag for sine børn. På menuen er der som de fleste aftner kebab og pomfritter med smeltet ost. Børnene skovler fastfooden ind med fingrene, direkte af plastikemballagen, mens de sidder på gulvet foran stuens store fladskærms-tv.

I denne sekvens konstruerer TV-serien et voyeuristisk middelklasseperspektiv på familien. Klassemedlemmerne patologiseres gennem det ulækre portræt, hvor de fremstår som dyr, der ikke engang besidder den mest elementære maddannelse: at spise af en tallerken ved et spisebord og bruge kniv og gaffel. Jamie understreger dog flere steder, at klasse ikke kan bruges som undskyldning for ikke at lave ordentlig mad: "God mad og god madlavning er ikke en klasseting - alle kan spise godt uanset husholdningsbudgettet." (Oliver, 10).

Ansvaret for børnenes problematiske spisevaner placeres entydigt hos moren i sekvensen hjemme hos Natasha. Vi ser kun børnenes far i baggrunden, mens Natascha erkender og angrer fejlernæringen af børnene med brødebetynget ansigt direkte i close-up til kameraet. Det er hendes ansvar, og hun bør bekende. Denne framing af den hulkende mor i joggingtøj er antimodellen til det almoderlige og agtværdige portræt af Marguerite Patten i kogebogens dedikation.

Natasha accepterer efter denne erkendelse at deltage i Jamies kurser, og det viser sig, at hun faktisk har talentet, og under Jamies guidning bliver hun "maddannet" og i stand til at tage sig af sine børn. Den transformerede Natasha figurer også i et opslag $\mathrm{i}$ kogebogen. På billedet fremviser hun stolt en stor stak hjemmelavede pandekager med friske jordbær. Hun smiler og udstråler nu handlekraft og overskud (Oliver, 204-205). I en tilhørende tekstboks forklarer hun, at takket være Jamies maddannelse er hendes 
moderlige drøm gået i opfyldelse, da familien nu sidder og spiser 'rigtig' mad sammen ved et bord. Natasha italesætter sit make-over som en rejse mod Jamies legitime (mad)kulturelle normer, som ligeledes tillader hende at performe en legitim form for moderskab. Realiseringen af maddannelsen synes at være bundet op på, at Natasha 'finder tilbage' til sin rolle som husmoder og tager det ansvar på sig.

Denne gastronomiske empowerment er uløseligt forbundet med aflæggelsen af illegitime livsstilsmønstre. Jamie vil ikke bare forbedre 'elevernes' gastronomiske kompetencer, men også lede dem tilbage til traditionelle kønsroller. Den gastronomiske uorden, som Natasha inkarnerer i starten, kan ikke løses uden at skabe 'kønnet orden' i hendes liv. På den måde definerer projektet legitime (Marguerite Patten) og illegitime kvinderoller (Natasha) og styrer derefter kvinderne fra en illegitim position til en legitim position, hvor kvinderoller konstrueres gennem moderskab.

Det er slående, at fortællingerne om de mænd, der tager del i Jamies maddannelses-projekt slet ikke kobler den kulinariske empowerment til faderskab. Der er i langt højere grad tale om et individualiseret og lystbetonet projekt. Fx Mick "the Miner", som både spiller en central rolle i TV-serien og i kogebogen som inkarnationen af den traditionelle arbejderklassemand, der ikke gider beskæftige sig med madlavning. Han kommer dog på bedre tanker efter mødet med Jamie. Mick udtrykker en personlig glæde over at have lært at lave mad, men den påvirker ikke hans forhold til familien selvom han har én. Denne kønnede forskellighed accentueres også ved det, at Mike konsekvent omtales med sin jobtitel (Mick the Miner), mens Natashas identitet defineres i forhold til moderskabet ("Mum to two"). Natasha rammes derfor dobbelthårdt af Jamies gastrogouvernementalistiske projekt. Mick skal 'kun' disciplineres kulinarisk og påtage sig de medfølgende middelklassenormer om, at madlavning fra bunden er en konstituerende del af et ordenligt liv. Natasha iscenesættes både før og efter sit make-over udelukkende via sit moderskab. Først som en forfærdelig mor, så som en mor, hvis familiedrøm er fuldbragt - takket være Jamie Oliver. Således fastholder projektet en klassisk kønsdikotomi i den vesterlandske madkultur mellem kvindelig madlavning som et care-for-others-projekt og mandlig madlavning som et care-for-self-projekt (Lupton), som DeVault altså også fandt i sine studier (DeVault). 


\section{GORDON OG DE TO BRIDGET JONES}

Hvor Jamie Oliver fra sine første programmer tog afstand fra kokkerollen, så omfavner den britiske kok Gordon Ramsey den og dens krævende smagsidealer. Han optræder meget ofte i uniform og skaber sin maskulinitet omkring den hårde restaurantkøkkenkultur (Steno og Friche). Han fik sit gennembrud med dokumentarserierne Boiling Point og Beyond Boiling Point fra sluthalvfemserne, hvor man fulgte arbejdet i det opkogte køkken på hans restaurant. Her drev han sit personale diktatorisk i jagten på at få de forjættede tre Michelinstjerner. Hans brutale tone over for de ansatte gjorde ham til en yderst kontroversiel herre. Sidenhen dannede restaurantkøkkenet dog platform for en række TV-koncepter med ham som frontfigur, ikke mindst Hell's Kitchen. Det er et TV-konkurrencekoncept, hvor forskellige køkkenlærlinge konkurrerer i et professionelt køkken, som Ramsey bestyrer, og med samme verbale og fysiske hårdhed som i dokumentarerne evaluerer han kandidaterne. ${ }^{5}$

Gordon genopliver således hele den myte om den uniformerede mandlige kok, omend i en mere brutal og individualiseret udgave end i det traditionelle TV-køkken. Restaurantkøkkenets faste, patriarkalske orden forsøger han også i sine nyere programmer gennem forskellige madrelaterede strategier at eksportere til andre dele af samfundet, som har en mere flydende og for Gordon mere uordentlig karakter. Det mest slående eksempel er hans såkaldte Getting-Women-Back-in-the-Kitchen-kampagne i programmet The F-Word, hvor Gordon forsøger at få kvinder til at "genfinde glæden" ved at lave mad. ${ }^{6}$

5 Den svenske etnolog Gabriella Nilsson har malerisk beskrevet Hell's Kitchen i en artikel om fænomenet: "The hell promised in the programme's title, then, is a hell suffered by the cooks, not the diners. For anyone who passes the mental testing, the job is in 'a dream world'; for those who do not, 'their worst nightmare'. At the end of each episode, Ramsay determines who is not up to the mark and must leave the competition. After 15 programmes, one winner remains, who has proved worthy according to Ramsay's 'standards'. In the course of the programmes, Ramsay engages in loud tongue-lashings, insulting invectives and continual swearing." (Nilsson 2012, 2).

6 The F-word kørte med Gordon Ramsay som vært over fem sæsoner fra 2005-2009 med varierende episodeantal og forskellige nye tiltag i hver sæson. Første sæson af madprogrammet bestod af i alt 9 episoder, der blev vist fra d. 27. oktober 2005 og ni 
I en episode skal han lave et make-over af to modne kvinder i sluttrediverne, Naomi og Georgina, som bor sammen i en lejlighed. De omtales dog konsekvent som to Bridget Jones'er med henvisning til sluthalvfemserheltinden Bridget Jones. Hun blev skabt af den britiske journalist og forfatter Helen Fielding, først i klumme, senere i bogform og siden på film. De to kvinders lejlighed er gennemsyret af uordentlighed. De kan ikke lave mad, og deres køkken fungerer primært som bar, hvor der til Gordons fortørnelse laves masser af cocktails og daiquiris i weekenderne. Nærmest som en forlængelse af deres kulinariske inkompetence og deres 'misbrug' af køkkenet, iscenesættes deres bofællesskab som en uønskelig situation og som en upassende forvaltning af deres liv, da de begge er modne kvinder, som i stedet for at feste sig igennem livet burde følge deres 'naturlige' skæbne og bruge deres kroppe til at producere børn (i stedet for branderter), og det vel at mærke inden deres biologiske ure om kort tid tikker ud. Deres kulinariske inkompetence er altså et symptom på et større problem: De er stagneret i en teenageragtig tilværelse med fest, alkohol og - må man formode, hvis de er ægte Bridget Jones'er - en masse tilfældig sex. De to partypigers uansvarlige tilværelse gør, at de - i programmets og Gordons beskrivelse - er nødt til at leve i et 'unaturligt' fællesskab med to personer af samme køn og uden børn.

Gordon kobler således den gastronomiske make-over med en romantisk make-over, da han ikke bare viser de to, hvordan man skal lave en middag, som enhver mand drømmer om: "Oldfashion steak and chips". Han tager også ud i byen og støver to dates - og potentielle familiefædre - op på den lokale gågade. Da de kommer, tjekker Gordon, at de to middagsgæster har taget blomster med, og sørger for, at alt er arrangeret efter traditionelle koder for det romantiske heteroseksuelle møde: Kvinderne laver mad og stadser sig ud, mændene tager blomster med og er smagsdommere over kvindernes kogekunst. Således instrueret sætter de fire sig ved et firkantet bord med en mand og en kvinde på hver side, således at de fire personer tydeligt er delt op i 'forståelige' parvise enheder med entydigt modsatkønnet begærsretning.

uger frem på kanalen Channel 4, der har været en britisk public service kanal siden 1982. Episoden med de to Bridget Jones'er er nummer fire i denne første sæson, men kampagnen for at få kvinderne tilbage i køkkenet kørte over hele sæsonen. 
Gordon udstyrer ikke bare kvinderne med gastronomiske kompetencer, han 'leder' dem fra deres nuværende upassende - ja, nærmest 'perverse' - situation ind i deres 'naturlige' plads i den heteroseksuelle matrice. I denne sekvens udvider Gordon sin rolle som leder i restaurantkøkkenet til også at omhandle social ledelse og styring af subjekter i verden uden for det professionelle køkken, og viser, at man kan overføre den orden, disciplin og selvkontrol, der hersker i det professionelle køkken til at genskabe orden i den flydende modernitet. Han er ikke bare en gastronomisk mentor, han er en 'leder', der disciplinerer uordentlige subjekter ved at styre deres amoralske sociale ageren mod en mere 'hensigtsmæssig'- dvs. samfundsbevarende og heteronormativ - opførsel gennem gastronomisk 'empowerment'.

I dette eksempel er der som i Jamie's Ministry of Food tale om en patologisering, men den er ikke direkte møntet på arbejderklassen - begge party girls fremstår veluddannede og med økonomisk råderum - det er deres forvaltning af deres kroppe, der patologiseres, altså deres postfeministiske livsstil, hvor de som Bridget Jones-kloner repræsenterer en type kvinder, som fik stor plads i 1990'erne med TV-serier som Sex and The City og Ally (Moseley og Read). Fælles for disse postfeministiske kvinder var, at de er veluddannede kvinder, der lever uden for faste parforhold og shopper mellem forskellige mænd. De agerer således seksuelt og økonomiske frigjorte - i hvert fald til en vis grænse - fra mænds økonomiske og seksuelle dominans (McRobbie). ${ }^{7}$ I Gordons framing af Naomi og Georgina fremstår

7 Der er ikke nogen entydig definition af postfeminismen, men en af de mest betydningsfulde forskere inden for denne bevægelse, Angela McRobbie, beskriver det postfeministiske landskab således i en af sine senere bøger, The Aftermath of Feminism fra 2009, hvor hun ser kritisk tilbage på tendensen: "a situation which is marked by a new kind of anti-feminist sentiment which is different from simply being a question of backlash... Drawing on a vocabulary that includes words like 'empowerment' and 'choice', these elements are then converted into a much more individualistic discourse, and they are deployed in this new guise, particularly in media and popular culture, but also by agencies of the state, as a kind of substitute for feminism. These new and seemingly 'modern' ideas about women and especially young women are then disseminated more aggressively, so as to ensure that a new women's movement will not re-emerge... Freedom is revitalized and brought up-to-date with this faux-feminism" (McRobbie 1). 
deres postfeministiske livsstil som syg, hvilket ikke mindst kommer frem gennem den konstante betoning af deres alkoholforbrug, der bliver symbolet og symptomet på deres frivole livsform, som Gordon vil sætte en stopper for. Det kan han gøre gennem maddannelsen, der vil lede dem hen mod et stabilt heteroseksuelt forhold.

\section{NÅR KOKKEN SLÅR TILBAGE MOD MÆNDENE}

Et interessant eksempel på en lignende form for gastrogouvernementalitet på tv, som i sin kønsnormativitet adskiller sig fra Jamie's Ministry of Food og Gordons "Getting Women back in the Kitchen"-kampagne, finder man i en episode af programmet Le ChefContre-attaque $(\mathrm{M} 6,2009)$ med Cyril Lignac. ${ }^{8}$ Cyril Lignac har siden sin debut på tv i 2004 haft en række madprogrammer på M6 (Mantoux \& Rubin, 27), som er Frankrigs tredje mest sete kanal. ${ }^{9}$ Desuden har Cyril Lignac været vært og dommer ved de franske udgaver af Masterchef og Den store Bagedyst. Parallelt hermed har han udgivet mere end 40 kogebøger. Han er således den absolut største 'chef star' i Frankrig og har opbygget et større imperium ved frugtbart at kombinere rollen som professionel kok med roller som restauratør, madentreprenør og mediestjerne. Han fremstår som en dynamisk moderne mand, der modsat Jamie og Gordon også rummer et touch af noget metroseksuelt qua sin lange, slanke figur, sit altid perfekte stylede hår og sin næsten venindeagtige omgang med seeren.

Præmissen for Le Chef Contre-attaque er, at i dagens Frankrig arbejder 70 \% af kvinderne, men det er stadigvæk dem, der står for det huslige arbejde - ikke mindst madlavningen. Cyril tager til Lens i det nordlige Frankrig for at gøre noget ved problemet. Her følger vi hans forsøg på at 'omvende' tre mænd, der aldrig har deltaget i madlavningen i hjemmet, og få dem til at bidrage til husarbejdet som 'moderne' mænd.

8 Le Chef Contre-attaque behandlede en ny "défi culinaire" i hver episode, således problematiseres mænds forhold til madlavning kun i dette ene afsnit. Programmerne, der varede halvanden time, blev sendt mellem 2008-2010. Udsendelsen om at få mændene i køkkenet blev sendt d. 16. februar 2009 jf. http://www.m6.fr/ emission-le_chef_contre_attaque/emission-le_chef_contre_attaque.html (besøgt d. 22. september 2015)

9 Jf. http://fr.wikipedia.org/wiki/M6 (besøgt d. 15. maj 2014) 
Programmet begynder med, at vi ser Cyril gå rundt i Lens. Han stopper forskellige grupper af mænd - alle håndværkere, som er i gang med dagens dont - og spørger dem, om de laver mad. Alle svarer "nej" og påpeger, at det er "madame", der står for det. Cyril borer i, hvorfor det er sådan, når nu "madame" også arbejder. De forskellige mænd replicerer lettere fnisende, at det har de ikke tid til, eller at deres koner er så gode til det, at det ville være dumt at lave om på rollerne. Denne holdning genfinder man hos de tre mænd, der skal omvendes. Ikke mindst Jean-Luc, en 56-årig lastbilchauffør, der skråsikkert udbryder, at "madlavning, det er kvindearbejde!", mens han slår håndfladerne sammen for at understrege sin pointe. En holdning, der deles af de to yngre mænd, som er med i eksperimentet, hvor den ene, Cédric, hellere vil spille computer med sine drenge end at hjælpe konen, mens den anden, Greg, hellere vil snakke med kammeraterne på den lokale bodega eller tage til fodboldkamp.

Cyril interviewer også forskellige kvinder i byen, der alle siger, at de er trætte af at lave det hele, og at deres mænd er nogle 'machoer'. Derpå konkluderer Cyril direkte til kameraet, at det er utroligt, at man kan finde sådanne holdninger i dagens Frankrig. Han har virkelig lyst til at kæmpe for at ændre dette billede. Herefter ser vi den indignerede, unge mand løbe over vejen for at engagere sig i kampen, mens voice-over'en annoncerer: "I aften går Cyril sig sammen med kvinderne."

I løbet af programmet udstilles disse tre mænds kulinariske inkompetencer gentagne gange. Mest insisterende i starten, hvor de får til opgave at lave almindelige retter til aftensmad uden opskrift. Her dvæles længe ved deres manglende færdigheder. Først i supermarkedet, hvor de fremstår helt på herrens mark og bliver nødt til at fåtilfældige kunder til at hjælpe dem med at finde de mest basale ingredienser. I køkkenet fortsætter den karnevaleske latterliggørelse, og det bliver accentueret i hvor høj grad, de tre mænd er på fremmed grund; én prøver at purere en grøntsagssuppe med et piskeris, og en anden river ovndøren af, da han skal åbne ovnen. Da Jean-Luc efter en lang kamp i køkkenet kan præsentere en forfejlet ostesoufflé, bryder både Jean-Lucs kone og datter anført af Cyril ud i en langvarig latterkrampe.

Under Cyrils coaching gennemgår de tre mænd dog en radikal udvikling og begynder at få styr på madlavning. De tre mænd består endda med bravour den afsluttende test, som består i at lave en middag for et udvalg 
af byens kvinder. Det går ligefrem så vidt, at den før så afvisende Jean-Luc fortæller, at fremover vil han irettesætte mænd, der siger, de ikke kan lave mad, og belærer dem om, at "hvis du vil, så kan du!". Som en del af JeanLucs forvandling overrasker han også en aften sin kone med en forførende middag med kammuslinger og foie gras serveret i stearinlysets skær og med flot hvid dug på bordet. Et træk, der får glædestårerne frem hos den før så frustrerede hustru. Nu føler hun sig hensat til en restaurant i sit eget hjem.

Denne udsendelse følger samme formel som de to andre programmer, hvor en kulinarisk inkompetence kobles med et større moralsk problem, som synes at bunde i forkerte måder at gøre køn på. Her er det blot den traditionelle og ufleksible manderolle, der patologiseres. Igen kommer TV-kokken med løsningen på det kulinariske problem, som også åbner for en løsning af det 'større' problem. I serien eksemplificeres dette særligt gennem Jean-Lucs transformation fra gammeldags machomand til én, der tager det hjemlige køkken til sig og kæler for sin kone. Det er bemærkelsesværdigt, at Jean-Lucs forvandling til en moderne ligestillingsorienteret mand synes at være meget tæt forbundet med en omfavnelse af middelklassens idealer for mad og levevis. I sin analyse af køn, klasse og madlavning fremhæver den amerikanske sociolog Majorie Devault, at middelklassefamilier ofte betoner, at "de gør noget ud af måltidet" og at de "elsker at prøve noget nyt" (Devault, 203-226). ${ }^{10}$ Disse to idealer fungerer ofte distinktivt i forhold til familier fra de lavere klasser, der betoner rigelighed, uformalitet og tradition, hvilket også i udgangspunktet betegnede Jean-Lucs familie. Når Jean-Luc laver romantisk middag, gør han "noget ud af måltidet", da han transformerer den kedelige spisestue til et stilfuldt restaurantlignende rum med hvid dug, stearinlys og foldede servietter. Endvidere serverer han nye komplicerede retter, som han præsenterer i et sofistikeret menukortsprog. For at kunne blive en moderne mand synes det altså nødvendigt for Jean-Luc at omfavne middelklassens idealer for mad og måltider.

I modsætning til i Jamie's Ministry of Food og i Gordons "Getting the Women Back in the Kitchen"-kampagne er der her ikke tale om, at en

10 Devaults pointer ligner til forveksling de konklusioner, Bourdieu drager på baggrund af en lignende undersøgelse i den madsociologiske klassiker La Distinction (Bourdieu). 
mandlig stjernekok 'banker' kvinder på plads. Tværtimod leder kokken traditionelle mænd ind i roller, der ifølge værten er mere passende til det 21. århundrede. Herved er det ikke bestemte kvinderoller, der patologiseres eller gøres illegitime, men derimod den traditionelle manderolle. ${ }^{11}$

En interessant parallel til Jamie's Ministry of Food er dog, at den illegitime kønsposition er stærkt knyttet til klasse. Som Jamie tager Cyril 'nordpå'. Den 'geostereotype' fremstilling af Nordengland og Nordfrankrig er i programmerne relativt identisk, da disse regioner beskrives som uglamourøse og tilbagestående industriområder. Disse territorier er endvidere beboet af arbejderklassen og er derfor ikke på samme udviklingsstadie som de sydligere metropoler, hvor TV-kokkene til dagligt udfolder sig. De tre mænd, der deltager i Le Chef Contre-attaque, passer ind denne stereotyp om den tilbagestående 'nordbo', og mændenes inkompetence i køkkenet er med til at udstille, at deres forståelse af køn hører et andet århundrede til. Som i Jamie's Ministry of Food inviteres seeren til at dele programmets middelklasse blik på og udstilling af arbejderklassens medlemmer. Gennem sin afstandtagen til denne 'tilbagestående' maskulinitetsposition konstruerer Cyril sig selv som en 'moderne' mand, der er fulgt med tiden. Cyril bruger idealerne om ligestilling til at etablere et nyt kønshierarki, hvor den moderne middelklassemaskulinitet (som han selv inkarnerer) rangeres over den traditionelle arbejdermaskulinitet. Herved kobles ligestillingsdebatten til et klassespørgsmål, der er med til at afskære middelklassemanden fra den feministiske debat, da ligestilling kommer til at fremstå som et fait accompli i middelklassen. Serien reducerer kønslighedsspørgsmål og feministiske diskussioner til problemstillinger, der kun er aktuelle i de lavere klasser og i 'Udkantsfrankrig' (Leer, in press).

\section{TV-KOKKEN SOM KØNSOPDRAGER}

Fælles for disse tre analyser er altså, at TV-kokken gennem tilbuddet om at maddanne 'usunde' medborgere også forsøger at styre deres måde at gøre køn på, da maddannelse i programmernes konstruktion er uløseligt 
forbundet med bestemte måder at legitimere og illegitimere kønsroller. Det er med dette for øje, at jeg vil mene, at man kan tale om en tendens, der følger samme struktur, hvor manglende maddannelse kobles til et større problematisering af måder at gøre køn på. TV-kokken tilbyder i alle eksemplerne et make-over, der både kan hjælpe den kulinariske og kønsmæssige krise.

Diagnosticeringen af problemerne og de medfølgende patologisering af bestemte individer, der inkarnerer problemet, er dog lidt forskellige, ligesom idealerne for køn divergerer i de tre programmer. I Jamie's Ministry of Food var diagnosen, at den tiltagende fedmeepedimi var et udtryk for arbejderklassemødrenes svigt. I Gordons kampagne blev kvindernes manglende madkompetencer tolket som et symptom på, at mange moderne kvinder levede for frigjort og ansvarsløst, og dermed har de ifølge programmet og Gordon mistet kontakten med deres "naturlige" kvindelighed. I begge disse eksempler så den mandlige TV-kok det som sin opgave at lede kvinden tilbage til den traditionelle kvinderolle. Heroverfor repræsenterede Le Chef Contre-attaque et interessant modeksempel, da missionen her var at lede traditionelle mænd mod moderne maskulinitetsroller. Igennem denne velmenende entreprise opstod så et nyt hierarki mellem den urbane middelklasse mand og den traditionelle, provinsielle arbejdermand.

Således reproducerer denne tendens, hvor TV-kokken kobler madaktivisme og kønsmake-over, altså ikke kun en ulige kønsorden mellem mænd og kvinder; eksemplet med Le Chef-Contre-attaque viser også, at sådanne maddannelsesprogrammer kan konstruere hierarkier mellem forskellige typer af legitim og illegitim maskulinitet. Der er derfor også meget at kritisere i Le Chef Contra-attaque fra en feministisk optik på trods af programmets ambition om at skabe større kønslighed. Et andet kritikpunkt er programmernes neoliberale logik, som går igen i artiklens tre analyseeksempler, hvorved komplicerede problematikker om køn log mad) gøres til individuelle problemer, og herved løsrives disse problemstillinger fra mere generelle, samfundsmæssige strukturer. Igennem den neoliberale logik patologiseres ikke bare de forskellige usunde mænd og kvinder, som kendiskokkene vil lave om på, men også enhver som ikke udviser vilje til at ville ændre sin livstil efter kendiskokkens dessiner. Som 
den omvendte Jean-Luc på smukkeste neoliberale vis udtrykker det: "Hvis du vil, så kan du!".

Således rummer disse moderne, aktivistiske madprogrammer både ligheder og forskelle med Marguerite Pattens madprogrammer, som var nogle af de første madprogrammer i en europæisk kontekst. Marguerite Pattens BBC-programmer fra 1940-1950'erne adresserede entydigt husmoderen og husmoderens arbejde i køkkenet - og i hjemmet generelt - blev tillagt værdi og samfundsmæssig vigtighed. Den britiske medieforsker Rachel Moesley argumenterer for, at selvom forskellige og modstridende diskurser om kvindelighed blev forhandlet i programmerne - særligt forholdet mellem kvinden som privat og i stigende grad også offentlig person qua sin indtræden på arbejdsmarkedet - så opererede programmerne som en "hegemonisk kønsteknologi" (Moseley 2009, 28). Via formidling af viden om madlavning og husholdning blev rammerne for passende kvindelighed nemlig tegnet op og afgrænset via en offentlig kanal. I de tre eksempler, jeg har analyseret her, finder vi samme optegning og afgrænsning af passende kønsroller. Endvidere er det (ned)slående, hvor tæt Pattens og Jamies og Gordons kvindeidealet er på hinanden. Det franske eksempel minder os dog om, at vi lever i en tid, hvor der er konkurrerende bud på, hvad der udgør passende og ikke mindst upassende måder at gøre køn på, og der dermed er kamp om hegemonien. Alle analyseeksemplerne bør dog forstås som en hegemonisk teknologi til at definere og styre kønnede (og 'klassede') identiteter og hierarkier via maddannelse. Hvor det på Pattens tid var kvinder, der definerede passende kvindelighed i madprogrammerne, så er det i dag i høj grad også blevet mandlige madstjerner, der har indtaget rollen som kønsopdrager via maddannelse.

Jonatan Leer er postdoc ved Aarhus Universitet under forskningsprojektet Smag for Livet (www.smagforlivet.dk). Han har forsket i madkultur i en årrække med særlig fokus på mad og maskulinitet, hvilket også var emnet for hans ph.d.-afhandling Ma(d)skulinitet. Hans nuværende forskning drejer sig også om smagspædagogik, børnekogebøger og gastronationalisme. Han har netop været redaktør på et temanummer af Social Kritik om det ny nordiske køkken og er på vej med antologien Food and Media: Practices, Distinctions and Heterotopias hos Ashgate. Jonatan har en fortid som restaurantanmelder og kogekone. 


\section{THE TV CHEF AS GENDER INSTRUCTOR}

Controlling Gender through Food Literacy in Jamie's Ministry of Food, The F-word and Le Chef Contre-attaque

This article explores the gendering of a series of new formats of food television in which male TV-chefs goes from being lifestyle expert to social and moral entrepreneurs as they engage in food activist project to better national food culture. These readings draws on Foucault's term "governmentality," the reworking of this concept in relation to food education and food literacy. The article argues that we see a tendency in which male celebrity chefs use cooking classes and promises of food literacy to make distinctions between legitimate and illegitimate gender identities. These hierarchies are not only created between men and women, they also create hierarchies between middle-class and working-class masculinity.

Keywords: governmentality, food education, food literacy, gender, media

\section{LITTERATUR}

Aarseth, Helene and Olsen, Bente M. "Food and Masculinity in dual-career couples". Journal of Gender Studies 17 (2008): 277-287.

Benn, Jette. "Food, Nutrition or Cooking Literacy - A Review of Concepts and Competencies Regarding Food Education". International Journal of Home Economics 7 (2014): 13-35

Belasco, Warren. Food. New York: Berg, 2008.

Bourdieu, Pierre. La distinction. Paris: Les Éditions de Minuit, 1979.

Counihan, Carole and Van Esterik, Penny. Food and Culture. New York: Routledge, 2008.

Counihan, Carole, Kjær, Katrine Meldgaard og Leer, Jonatan. "More Than 'Add Women and Stir' - A Conversation with Carole Counihan." Kvinder, Køn og Forskning 23 (2015/in press)

Coveney, John, Begley, Andrea, \& Gallegos, Daniella. "'Savoir Fare': Are cooking skills a new morality?" Australian Journal of Adult Learning 52 (2012): 617-642

DeVault, Majorie. Feeding the Family: The Social Organization of Caring as Gendered Work. Chicago: University of Chicago Press, 1991.

Foucault, Michel. Sikkerhed, territorium, befolkning. København: Gyldendal, 2008.

Foucault, Michel. Biopolitikkens fødsel. København: Gyldendal, 2009.

Fuglsang, Jon. "Maddannelse". Madsociologi. Red. Jon Fuglsang og Naja Stamer. København: Munksgaard, 2015. 197-214.

Hollows, Joanne. "Oliver's Twist: Leisure, Labour and Domestic Masculinity in The Naked Chef". International Journal of Cultural Studies 6 (2003): 229-248. 
Hollows, Joanne. "The Worst Mum in Britain" in Leer, Jonatan \& Klitgaard Povlsen, Karen (eds.) Media Food: Politics, Practices and Identities. London: Ashgate, 2016/in press. Hollows, Joanne \& Jones, Steve. "'At least He's Doing Something': Moral entrepreneurship and individual responsibility in Jamie's Ministry of Food", European Journal of Cultural Studies 13 (2010): 307-322.

Jensen, Anders F.. Mellem ting. Foucaults filosofi. København: Det lille forlag, 2005. Johnston, Josée and Baumann, Shyon. Foodies. New York: Routledge, 2010.

Leer, Jonatan. $\mathrm{Ma}(\mathrm{d})$ skulinitet: maskulinitetskonstruktion i europæiske madprogrammer efter The Naked Chef $i$ lyset af "den maskuline krise" (Ph.d.-afhandling). Københavns Universitet, 2014a.

Leer, Jonatan. "Jamie Oliver i den gode smags tjeneste". Litteraturmagasinet Standart 28 (2014b): 54-57.

Leer, Jonatan. "If you want to, you can do it!": Home cooking and masculinity make-over in Le Chef Contre-Attaque. Food, Masculinities and Home Red. Michelle Szabo og Shirley Koch. New York: Bloomsbury Academic, 2016/in press.

Lupton, Deborah. Food, the Body and the Self. London: Sage Publications, 1996.

Mantoux, Aymeric, et Rubin, Emmanuel. Le livre noir de la gastronomie française. Paris: Flammarion, 2011.

McRobbie, Angela. The Aftermath of Feminism. London: Sage, 2009.

Moseley, Rachel. "Real Lads Do Cook... But Some Things are Still Hard to Talk About: The gendering 8-9". European Journal of Cultural Studies 4 (2001): 32-39.

Moseley, Rachel. Marguerite Patten. "Television Cookery and Postwar British Femininity". Feminism, Domesticity and Popular Culture. Red. Stacy Gillis og Joanne Hollows. London: Routledge, 2009. 17-32.

Moseley, Rachel og Read, Jacinda. "Having it all': Popular Television (Post-)feminism." Feminist Media Studies 2 (2002): 231-249.

Nilsson, Gabriella. "Ball's Enough: Manliness and Legitimate Violence in Hell's Kitchen." Gender, Work, and Organization 6 (2012): 1-17.

Oliver, Jamie. Jamie's Ministry of Food. London: Michael Joseph, 2008.

Povlsen, Karen Klitgaard, Kjær, Katrine Meldgaard og Leer, Jonatan. "Food, Gender and Media - the Trinity of Bad Taste: A Conversation with Karen Klitgaard Povlsen." Kvinder, Køn og Forskning, 23 (4/2015).

Steno, Anne Mia, and Nanna Friche. Celebrity chefs and masculinities among male cookery trainees in vocational education. Journal of Vocational Education \& Training 67 (1/2015): 47-61.

Strange, Niki. "Perform, Educate, Entertain: Ingredients of the Cookery Programme Genre". Red. Claire Geraghty og David Lusted: The Television Studies Book. London: Arnold, 1999. 77-85.

Søndergaard, Dorte Marie. Tegnet på kroppen. København: Museum Tusculanum Press, 1996.

Szabo, Michelle. "Men nurturing through food: Challenging gender dichotomies around domestic cooking". Journal of Gender Studies 23 (2014): 18-31. 